\title{
Ontwikkelingen in het
}

\section{leesbaarheidsonderzoek van}

\section{narratieve accountingteksten}

Dick Feenstra

SAMENVATTING De leesbaarheid van narratieve accountingteksten wordt traditioneel bepaald met behulp van een of meer leesbaarheidsformules. Deze formules, waarvan er drie worden besproken, zijn in de literatuur ernstig bekritiseerd. De toepassingen binnen accounting zijn dientengevolge aanvechtbaar. In het moderne leesbaarheidsonderzoek staat het sociaalpsychologische paradigma impressiemanagement centraal. Binnen dit paradigma wordt onderzocht hoe de ondernemingsleiding de informatieasymmetrie tussen de leiding en buitenstaanders benut in de vorm van vertekeningen in de externe verslaggeving. Manipulaties door middel van het gebruik van taal kunnen daartoe worden aangewend. Er worden veel voorbeelden gegeven van accountingstudies waarin verschillende soorten manipulatiestrategieën met betrekking tot het taalgebruik worden besproken. Meer en meer worden in het accountingonderzoek concepten uit de psychologie en de letteren toegepast. In het artikel worden in dit kader suggesties gedaan voor toekomstig onderzoek.

RELEVANTIE VOOR DE PRAKTIJK Goed leesbare directieverslagen zijn van belang voor de beoordeling van de gang van zaken in organisaties en voor de vermogensallocatiebeslissingen van beleggers. Zowel uit traditioneel als uit modern leesbaarheidsonderzoek blijkt evenwel dat directieverslagen veelal moeilijk te lezen zijn. De manier waarop leesbaarheid wordt gemeten is echter aanvechtbaar. Het moderne leesbaarheidsonderzoek kan suggesties opleveren ter verbetering van de leesbaarheid.

\section{Inleiding}

$\mathrm{Na}$ het overzichtsartikel van Jones en Shoemaker (1994) over de leesbaarheid van kwalitatieve accountingteksten ('accounting narratives') hebben zich belangrijke ontwikkelingen voltrokken in de literatuur en de verslaggevingspraktijk ter zake. In de literatuur valt een paradigmawisseling op: van hoofdzakelijk syntactische studies met leesbaarheidsformules naar studies die vanuit het sociaalpsychologische impressiemanagement-paradigma worden verricht. Deze paradigmawisseling vond uiteraard niet vanzelf plaats, maar is het resultaat van bezinning op methodologische uitgangspunten. In de paragrafen 2 en 3 van dit artikel bespreken we de inhoudelijke veranderingen in de bedoelde literatuur meer in detail.

Ook in breder maatschappelijk perspectief gezien bestaat er belangstelling voor leesbaarheid en begrijpelijke taal. Zo is in oktober 2011 door de Nederlandse Organisatie voor Wetenschappelijk Onderzoek (NWO) een oproep gedaan onderzoekvoorstellen in te dienen in het kader van het onderzoekprogramma 'Begrijpelijke taal: Fundamenten en toepassingen van effectieve communicatie'. Dit programma omvat de volgende vijf hoofdthema's waarvan het mogelijk belang voor accounting evident is:

1. Tekstkenmerken;

2. Lezerskenmerken;

3. Verschijningsvormen;

4. Effect; en

5. Bruikbaarheid.

Op het eerste gezicht wekt dit programma enige verbazing. Er worden toch al bijna honderd jaar lang pogingen ondernomen de leesbaarheid van teksten in relatie tot het opleidingsniveau van lezers te meten (Staphorsius, 1994)? Kennelijk zijn er ontwikkelingen gaande die een herbezinning rechtvaardigen. Later in dit artikel zal blijken dat dit inderdaad het geval is.

Regelgevende organen zoals de Securities and Exchange Commission (SEC), de International Accounting Standards Board (IASB) en de Raad voor de Jaarverslaggeving (RJ) in Nederland, hebben zich enkele malen uitgelaten over de leesbaarheid van narratieve accountingteksten. Het meest direct is het Plain English Handbook van de SEC (1998). Regelgevende organen zoals de IASB en de RJ verwijzen indirect via de zogenaamde kwalitatieve kenmerken betrouwbaarheid en neutraliteit naar aspecten van de taal. ${ }^{1}$ Immers, betrouwbaarheid impliceert dat wezenlijke onjuistheden niet mogen voorkomen, terwijl neutraliteit (ook wel: onpartijdigheid) inhoudt dat van vooringenomenheid geen sprake mag zijn.

Dit artikel beoogt inzicht te geven in ontwikkelingen binnen het leesbaarheidsonderzoek die wij onderkennen in 
Angelsaksische tijdschriften. Wij beperken ons tot reeds gepubliceerde boeken en tijdschriften; de veel op ssrn.com voorkomende en relevante artikelen laten we buiten beschouwing. Wij zullen de gesignaleerde ontwikkelingen in verband brengen met de sociale psychologie en de letteren. Het is opvallend dat in de Nederlandstalige accountingliteratuur aan de bedoelde ontwikkelingen vooralsnog geen aandacht is besteed. Dit is merkwaardig, omdat complexe en moeilijke taal het begrip van de lezers in negatieve zin kan beïnvloeden. Anders gezegd, de kwaliteit van de verstrekte informatie wordt aangetast, met mogelijk ernstige gevolgen voor het aantrekken van vermogen (Kothari et al., 2009). Daardoor kunnen de vermogensallocatiebeslissingen van beleggers suboptimaal worden. Er is daarom sprake van een niet te verwaarlozen probleem. Li (2010) noemt, iets algemener, drie redenen voor het belang van onderzoek naar tekstuele accountinginformatie (pp. 143-144):

1. '....can provide a very useful context for understanding the financial data and testing interesting economic hypothesis';

2. '...can provide a means for researchers to assess managers' behavorial biases and understand firm behavior';

3. '...provides researchers a powerful setting in which to understand managers' incentives and private information sets and therefore better understand firm behavior'.

Miller (2011) en Lehavy et al. (2011) hebben onlangs nog aangetoond dat beleggingsbeslissingen mede beïnvloed worden door taalkundige kenmerken van accountingteksten.

Dit artikel is als volgt gestructureerd. In paragraaf 2 bespreken we eerst het begrip leesbaarheid en de opkomst van het leesbaarheidsonderzoek in het algemeen. Leesbaarheidsformules worden expliciet besproken in paragraaf 2.2. In paragraaf 2.3 komt het traditionele leesbaarheidsonderzoek binnen accounting aan de orde, waarna we in paragraaf 2.4 eindigen met een beschouwing over het al dan niet samenvallen van de begrippen leesbaarheid en begrijpelijkheid.

Paragraaf 3 start met een bezinning op de paradigmawisseling die zich na het onderzoek van Jones en Shoemaker (1994) heeft gemanifesteerd. Daarbij passen enkele opmerkingen van methodologische aard. In deze paragraaf wordt slechts een deel van het moderne leesbaarheidsonderzoek door ons besproken. Wij kiezen ervoor slechts twee van de zeven door Merkl-Davies en Brennan (2007) onderscheiden manipulatiestrategieën te behandelen, en wel die strategieën waarbij door middel van taal wordt gemanipuleerd. Deze paragraaf wordt afgerond met enkele opmerkingen over de uit het vakgebied der letteren afkomstige genreanalyse.

In paragraaf 3.4 verbreden wij het perspectief door kort in te gaan op relevante ontwikkelingen binnen de letteren en de psychologie. Er worden enkele suggesties voor toe- komstig onderzoek gedaan. Paragraaf 4 besluit dit artikel met de voornaamste conclusies.

\section{Traditioneel leesbaarheidsonderzoek binnen accounting}

\subsection{Inleiding}

In de jaren twintig van de vorige eeuw ontwikkelden de Amerikaanse onderwijskundigen Vogel en Washburne (1928) een formule waarmee beoogd werd een verband te leggen tussen kenmerken van een tekst (bijv.: woord- en zinslengte, woorddiversiteit, woordfrequentie en het aantal voorzetsels) en het tekstbegrip van lezers. Geprobeerd werd vast te stellen in hoeverre diverse teksten geschikt zijn voor leerlingen met een uiteenlopend tekstbegrip. De door Vogel en Washburne (1928) ontwikkelde formule is een eenvoudige wiskundige vergelijking met enkele tekstkenmerken als onafhankelijke variabelen ter voorspelling van de begripsscore van lezers als afhankelijke variabele. Zo ontstond het in de vorige eeuw zo populaire leesbaarheidsonderzoek, waarbij taalkundige en syntactische complexiteit werden benadrukt. $^{2}$

Dit onderzoek is niet alleen in een onderwijsomgeving van belang gebleken, maar heeft ook van accountingonderzoekers aandacht gekregen. Met name de narratieve gedeelten van jaarrapporten zijn door tientallen onderzoekers geanalyseerd op hun leesbaarheid. ${ }^{3}$ Aanvankelijk beschouwden sommige accountingonderzoekers de begrippen leesbaarheid en begrijpelijkheid als synoniemen (bijv. Adelberg en Razek, 1984). Leesbaarheid en begrijpelijkheid kunnen in deze zienswijze tegelijkertijd worden gemeten met behulp van leesbaarheidsformules. Enkele van deze formules bespreken wij in paragraaf 2.2 In paragraaf 2.3 geven wij verschillende voorbeelden van toepassing ervan binnen accounting, om in paragraaf 2.4 weer terug te komen op de begrippen leesbaarheid en begrijpelijkheid.

\subsection{Leesbaarheidsformules}

Er bestaan veel alternatieve formules ter meting van de leesbaarheid van narratieve teksten. De overeenkomst tussen deze formules is dat de berekening van de moeilijkheidsgraad van teksten steeds wordt bepaald op basis van de lengte van gebruikte woorden en zinnen. Verschillen ontstaan onder andere door afwijkende interpretaties van de meting van het begrip woordlengte.

Wij geven hier drie voorbeelden van toegepaste formules; de voorbeelden 1 en 2 gelden voor de Engelse taal, terwijl voorbeeld 3 voor het Nederlands geldt.

1. $\mathrm{FLESCH}=206,385-0,846 \mathrm{~W}-0,015 \mathrm{Z}$

waarbij geldt:

$\mathrm{W}=$ woordlengte $=$ aantal letters $:$ aantal woorden;

$\mathrm{Z}=$ zinslengte $=$ aantal woorden $:$ aantal zinnen.

Dit is de door Flesch (1948) ontwikkelde formule die verreweg het meest wordt toegepast en in tal van populaire tekstverwerkingsprogramma's, zoals Microsoft Office Word en WordPerfect, is opgenomen. 
Hoe hoger een bepaalde tekst scoort, des te eenvoudiger wordt de leesbaarheid. Zo scoren teksten in Reader's Digest over het algemeen gemiddeld 65 , terwijl academische literatuur veelal minder dan 50 scoort en zeer specialistische teksten meestal minder dan 30 (zie Courtis, 1986, p. 286, [tabel 1]). In het vervolg van deze paragraaf zullen we zien dat narratieve accountingteksten laag scoren en dus als 'moeilijk' gelden.

2. FOG-index $=0,4(W+Z)$

waarbij geldt:

$\mathrm{W}=$ percentage 'moeilijke' woorden;

$\mathrm{Z}=$ zinslengte $=$ aantal woorden $:$ aantal zinnen.

Dit is de door Gunning (1952) ontwikkelde formule, die eveneens grote populariteit geniet.

Hoe hoger een bepaalde tekst scoort, des te complexer is de tekst. Krantenteksten bijvoorbeeld scoren veelal relatief laag (vaak minder dan 14), terwijl wetenschappelijke literatuur relatief hoge scores oplevert (vaak meer dan 17). ${ }^{4}$ De zwakte van deze formule zit in de term 'moeilijk'. Gunning benoemt bijvoorbeeld woorden van meer dan drie lettergrepen als moeilijk, evenals afkortingen. Het begrip 'moeilijk' wordt hierdoor op tamelijk arbitraire wijze versimpeld. In paragraaf 2.3. zullen we zien dat narratieve accountingteksten hoog scoren en dus als 'moeilijk' gelden.

3. CLIB $=46-6,603$ GWL + 0,474 PFREQ $-0,365$ TTR + 1,425 $\mathrm{GZpW}$

waarbij geldt:

$\mathrm{GWL}=$ gemiddelde woordlengte in letters;

PFREQ = percentage hoogfrequente woorden;

TTR = type token-ratio $(=$ antal verschillende woorden: totaal aantal woorden);

$\mathrm{GZpW}=$ gemiddeld aantal zinnen per woord.

Dit is de Nederlandse CITO Leesbaarheidsindex voor het Basisonderwijs (CLIB), zoals die in de jaren tachtig van de vorige eeuw werd ontwikkeld door het CITO en tot de dag van vandaag nog steeds in gebruik is voor het bepalen van de leesbaarheid van teksten gericht op kinderen in de leeftijd 7-12 jaar (Staphorsius, 1994). De formule is na uitgebreid wetenschappelijk onderzoek ontstaan en levert een globale indruk van de moeilijkheid van een tekst voor deze doelgroep. ${ }^{5}$ Er zijn geen toepassingen bekend op narratieve accountingteksten.

De drie gegeven voorbeelden kunnen met gemak worden uitgebreid tot meer dan tien (zie bijv. Wikipedia onder het trefwoord Readability).

De commentaren in wetenschappelijke tijdschriften op de leesbaarheidsformules lopen sterk uiteen. Enerzijds wordt in onderwijskundige kaders aan leesbaarheidsformules als predictie-instrument grote betekenis toegekend, anderzijds is er zoveel kritiek uitgeoefend op met name de validiteit ervan dat de populariteit in kringen van tekstonderzoekers sterk is afgenomen. De kritiek richt zich onder meer op de volgende punten (zie onder anderen: Klare,
1963; Anderson en Davison, 1988; Jansen en Lentz, 2008; Kraf en Pander Maat, 2009):

- Niet bewezen is dat door manipulatie van zins- en woordlengte het begrip van teksten verbeterd wordt.

- In de formules komen voor tekstbegrip essentiële zinsoverstijgende tekstkenmerken als samenhang en globale tekstopbouw ten onrechte niet voor.

- De interactie tussen lezer en tekst wordt eveneens niet in beschouwing genomen. De voorkennis, de geïnteresseerdheid en de vaardigheid van lezers wordt verwaarloosd. Dat geldt evenzeer voor grammaticale aspecten en diverse taalkundige formuleringen (actieve versus passieve vormen, de hantering van metaforen en verschillende stijlfiguren), maar ook voor typografische kenmerken (lettertype, tussenkopjes, diagrammen, grafieken, foto's, etc.).

- De formules zijn veelal ontwikkeld binnen het onderwijskundige kader van het basisonderwijs. Niet aangetoond is dat ze daarmee ook valide zijn met betrekking tot specialistische tekstgenres (zoals het jaarverslag) en hoogopgeleide gespecialiseerde lezers.

- Diverse statistische problemen worden veelal niet onderkend. Zo wordt de variantie van begripsscores binnen een lezersgroep vaak onderschat door gerichtheid op gemiddelde begrijpelijkheidsscores; tevens wordt de variantie binnen teksten onderschat door de gerichtheid op globale scores per tekst.

De meeste accountingonderzoekers zijn voorbijgegaan aan de zojuist genoemde bezwaren. Dat blijkt ook uit de in paragraaf 2.3 volgende samenvatting van de conclusies uit het overzichtsartikel van Jones en Shoemaker uit 1994.

\subsection{Toepassingen binnen accounting}

De hiervoor besproken leesbaarheidsformules zijn syntactisch van aard en geheel tekstgericht. Aan de gevolgen (pragmatische effecten) van teksten op lezers wordt volledig voorbijgegaan. In de beginperiode van het leesbaarheidsonderzoek binnen accounting, vanaf omstreeks 1950, staat de vaststelling van de moeilijkheidsgraad van narratieve teksten met behulp van dergelijke formules centraal. Later - beginnend in de jaren zeventig - komt er meer aandacht voor verschillen in de mate van leesbaarheid tussen verschillende narratieve gedeelten van jaarrapporten; tegelijkertijd begint men zich af te vragen met welke ondernemingskenmerken (omvang, winstgevendheid, etc.) leesbaarheidsscores van narratieve jaarrapportteksten samenhangen. Methodologische bezinning binnen accounting op de geschiktheid van de formules voor de vaststelling van de begrijpelijkheid van teksten treffen we pas vanaf het begin van de jaren negentig aan (Jones en Shoemaker, 1994).

Jones en Shoemaker hebben 32 accounting-leesbaarheidsonderzoeken, die tot en met 1993 gepubliceerd zijn, samengevat in de Journal of Accounting Literature (1994). Alle 
publicaties betreffen Engelstalige onderzoekingen, waarvan 21 afkomstig uit de Verenigde Staten, 4 uit het Verenigd Koninkrijk, 4 uit Australië, 2 uit Canada en 1 uit Nieuw-Zeeland. ${ }^{6}$ In 26 van de 32 publicaties is sprake van toepassing van (varianten van) de FLESCH-formule.

De 32 genoemde artikelen bestrijken de volgende vier probleemvelden:?

1. De al dan niet gebrekkige leesbaarheid van diverse narratieve onderdelen uit jaarrapporten.

2. Leesbaarheidsverschillen tussen diverse narratieve onderdelen uit jaarrapporten.

3. De eventuele samenhang tussen leesbaarheidsniveau en diverse ondernemingskarakteristieken.

4. Methodologische problemen.

Probleemveld 1 heeft verreweg de meeste aandacht gekregen, en niet alleen het directieverslag in enge zin (onder welke benaming dan ook), maar tevens de toelichting bij de jaarrekening, de accountantsverklaring, interimverslagen en prospectussen. De belangrijkste conclusie die in de beschouwde publicaties is getrokken blijkt zeer robuust te zijn en luidt als volgt: '... annual reports have proven difficult or very difficult to read because of sophisticated vocabulary and syntactical complexity' (Jones en Shoemaker, 1994, p. 173). Deze conclusie is robuust, omdat ze geldt voor alle gehanteerde leesbaarheidsmaatstaven, voor alle onderzochte (Angelsaksische) landen en voor alle onderzochte perioden. Ten aanzien van ontwikkelingen in de tijd stellen Jones en Shoemaker zelfs: '...the textual complexity of the annual report has increased over time...' (1994, p. 173).

De conclusie zoals bereikt in een achttal studies in het kader van het tweede probleemveld is in overeenstemming met die uit het eerste probleemveld: het maakt niet uit of het leesbaarheidsonderzoek gericht wordt op het directieverslag, de toelichting op de jaarrekening, de accountantsverklaring of de verslaggeving aan het personeel; steeds geldt de conclusie: 'difficult to read'.

In acht studies is de mate van samenhang tussen leesbaarheid en ondernemingskenmerken onderzocht. Nu blijken de conclusies minder eenduidig te zijn. Courtis (1986) vindt geen relatie tussen leesbaarheid en winstgevendheid, Baker en Kare (1992) kunnen geen eenduidig verband vaststellen, terwijl Subramanian et al. (1993) constateren dat de leesbaarheid juist toeneemt naarmate de ondernemingsprestaties verbeteren. Voor wat betreft de relatie tussen leesbaarheid en het ondernemingskenmerk omzet zijn de uitkomsten eveneens tegenstrijdig. Waar Jones (1988) constateert dat de leesbaarheid afneemt naarmate ondernemingen groter worden, vinden Baker en Kare (1992) het tegenovergestelde. Andere ondernemingskenmerken dan winstgevendheid en omzet zijn minder vaak in verband gebracht met leesbaarheid. Er is geen verband vastgesteld met het risicoprofiel (Courtis, 1986), het al dan niet failliet gaan (Smith en Taffler, 1992), met het controlerende accountantskantoor (Smith en Smith, 1971; Barnett en Leoffler, 1979) en met de percepties van aandeelhouders (Means, 1981). In het algemeen geldt dat er veelal geen significant verband is gevonden tussen leesbaarheid en diverse ondernemingskenmerken. Deze conclusie geldt zowel voor de twee studies waarin tijdreeksanalyses zijn uitgevoerd (i.c. Jones, 1988, en Smith en Taffler, 1992), als voor de overige studies waarin dwarsdoorsnedeanalyses zijn verricht.

Jones en Shoemaker (1994) hebben binnen accounting slechts één methodologische studie getraceerd, te weten Smith en Taffler (1992). In het werk van laatstgenoemden wordt gesteld dat de leesbaarheidsformules louter tekstkenmerken in beschouwing nemen en allerlei kenmerken van de lezers (bijv.: opleidingsniveau, deskundigheid, ervaring en geïnteresseerdheid) niet onderkennen. De formules zijn geheel syntactisch en dientengevolge zeer beperkt. De onderzoekers betwijfelen de geschiktheid van de formules om de begrijpelijkheid te meten en suggereren daartoe andere maatstaven. Ook Jones en Shoemaker (1994) zelf roepen in hun overzichtsartikel op tot een nadere bezinning op de validiteit en de betrouwbaarheid van de leesbaarheidsformules (p. 162 e.v.).

In paragraaf 2.4 gaan we daarom dieper in op de vraag of de met behulp van formules gemeten leesbaarheid gelijkgesteld kan/mag worden aan de begrijpelijkheid.

\subsection{Leesbaarheid en begrijpelijkheid}

\subsubsection{Inleiding}

De (syntactische) leesbaarheidsformules hebben een beperkte strekking; het draait in de meeste gevallen slechts om woord- en zinslengte. Het concept begrijpelijkheid omvat evenwel meer dan de bepaling van woord- en zinslengte en dient daarom anders gemeten te worden (Smith en Taffler, 1992; Staphorsius, 1994; Jones, 1997). ${ }^{8}$ Bij het concept begrijpelijkheid gaat het om kenmerken van de ontvangers van informatie en deze kenmerken blijven in de leesbaarheidsformules geheel buiten beeld. Naarmate bijvoorbeeld de relevante kennis van de lezers van directieverslagen toeneemt, zal het oordeel over de leesbaarheid en begrijpelijkheid ervan anders luiden dan het oordeel van volstrekte leken. Leesbaarheid en begrijpelijkheid zijn elkaar overlappende begrippen, waarbij begrijpelijkheid het ruimere begrip is.

Voor wat betreft de meting van het concept begrijpelijkheid wordt vaak een beroep gedaan op de Cloze-test (Taylor, 1953; Adelberg en Razek, 1984; Smith en Taffler, 1992; Staphorsius, 1994; Jones, 1997).' Waar leesbaarheidsformules louter tekstuele kenmerken in ogenschouw nemen, gaat het bij deze psycholinguïstische test om de inhoud van de tekst én kenmerken van de lezer, een en ander in onderling verband. De test werkt als volgt. In 
een narratieve tekst wordt elk $\mathrm{n}^{\mathrm{e}}$ woord weggelaten, waarna aan lezers wordt gevraagd de ontbrekende woorden in te vullen. Volgens Taylor (1953) wordt de begrijpelijkheid van teksten optimaal getoetst indien n op 5 wordt gesteld. Verdedigers van de Cloze-test stellen dat de methodiek niet alleen eenvoudig, maar ook betrouwbaar (Adelberg en Razek, 1984) en valide is (Stevens et al., 1992). Communicatiedeskundigen hebben de betrouwbaarheid van de test omstandig getoetst en concluderen onder andere dat Cloze-scores goed correleren met de percepties van lezers over de moeilijkheid van narratieve teksten en met inzichtmetingen door middel van multiple-choiceteksten (onder anderen Bormuth, 1966; Nestvold, 1972). In Nederland is de methodiek diepgaand beschreven door Staphorsius (1994).

\subsubsection{Toepassingen binnen accounting}

Jones (1997, tabel 1, pp. 110-114) geeft een overzicht van op dat moment bekende toepassingen van de Cloze-test op narratieve accountingteksten (onder anderen Adelberg, 1979 en Stevens et al., 1992). Het tekstbegrip bleek over het algemeen beperkt te zijn. Smith en Taffler (1992) concluderen in een experimentele onderzoeksopzet met accountingstudenten en ervaren praktijkdeskundigen, dat Clozetestscores slecht correleren met Flesch-scores. Dit is in het bijzonder het geval als de deskundigheid en/of de ervaring van de studenten relatief laag is; bij de praktijkdeskundigen werd een veel hogere samenhang gevonden (studenten 0,37; praktijkdeskundigen 0,73 ). Nagenoeg alle narratieve teksten werden met behulp van de FLESCH-maatstaf getypeerd als 'difficult to read'; de Cloze-scores laten een genuanceerder beeld zien: de moeilijke leesbaarheid blijkt niet voor alle groepen lezers te leiden tot een geringere begrijpelijkheid.

Jones (1997) is veel minder enthousiast over de toepassing van Cloze-testen op narratieve accountingteksten dan de zojuist genoemde onderzoekers. Hij baseert zijn opvattingen op die van vele critici van de test (1997, pp. 117-123); kritieken waarvan de meeste accountingonderzoekers zich volgens Jones niet bewust zijn. Wij vatten Jones' kritiek op de Cloze-test als volgt samen.

- Zolang er geen algemeen aanvaarde theorie bestaat inzake tekstbegrip is niet duidelijk wat de Cloze-test nu precies meet. Is het meten van de vaardigheid ontbrekende woorden te raden gelijk aan het concept begrijpelijkheid?

- Is het aanvaardbaar bij een bepaalde Cloze-testscore de grens te trekken tussen wel en niet begrijpen; en in hoeverre kan meer/minder begrijpen gemeten worden?

- Niet bewezen is dat een test die voor elementaire pedagogische doeleinden is ontwikkeld, zondermeer kan worden toegepast in de context van de begripsbepaling van narratieve accountingteksten.

- Er bestaat onduidelijkheid bij de vaststelling van de representativiteit (hoe groot dient een steekproef te zijn, hoeveel steekproeven dienen getrokken te worden, wanneer geldt een onderzochte groep als representatief?). Welke gevolgen heeft deze onduidelijkheid voor de generaliseerbaarheid van de verkregen uitkomsten? Jones' kritiek is ons inziens terecht. We concluderen daarom dat de twee begrippen leesbaarheid en begrijpelijkheid op aanvechtbare wijze worden gemeten. Nader onderzoek is noodzakelijk ten einde beter vat te krijgen op de meetbaarheid van deze begrippen als aspecten van de kwaliteit van accountingteksten. Maar welk paradigma kunnen we toepassen ter realisering van dit doel? In paragraaf 3.1 stellen we enkele gangbare alternatieven aan de orde. Aan de onder accountingonderzoekers betrekkelijk onbekende genreanalyse besteden we in paragraaf 3 apart aandacht, omdat met behulp ervan eveneens inzicht kan worden verkregen in mogelijkheden ter verbetering van de kwaliteit van accountingteksten.

\section{Modern leesbaarheidsonderzoek binnen accounting}

\subsection{Inleiding}

Dertien jaren na het overzichtsartikel van Jones en Shoemaker (1994) verscheen in de Journal of Accounting Literature opnieuw een overzichtsartikel over de leesbaarheid van narratieve accountingteksten, ditmaal van de hand van Merkl-Davies en Brennan (2007). Het begrip leesbaarheid is door Merkl-Davies en Brennan geanalyseerd in de context van de vrijwillige openbaarmaking van ondernemingsinformatie in ruime zin (directieverslagen, persmededelingen, voorspellingen, website-informatie). Het artikel past in de tijdgeest van het eerste decennium van de 21 eeuw: veel aandacht voor verslaggevingsschandalen en bezinning op wat nu eigenlijk kwalitatief goede verslaggeving is (Feenstra, 2011). Daarom is een groot deel van het omvangrijke overzichtsartikel gewijd aan impressiemanagement, waaromtrent gesteld wordt dat het de kwaliteit van de verslaggeving ondermijnt en dientengevolge kan leiden tot verkeerde vermogensallocatiebeslissingen (Merkl-Davies en Brennan, 2007, p. 159 e.v.; Kothari et al., 2009; Li, 2010; Miller, 2011). ${ }^{10}$ In Jones en Shoemaker (1994) speelde impressiemanagement nog geen rol van betekenis. Impressiemanagement - ook wel zelfpresentatie genoemd - is een vorm van opportunistisch gedrag van de ondernemingsleiding waarbij de informatieasymmetrie tussen de leiding en buitenstaanders wordt benut in de vorm van vertekeningen in de externe verslaggeving ('biased reporting'). In de woorden van Hooghiemstra (2000, p. 60): 'a field of study within social psychology studying how individuals present themselves to others to be perceived favourably by others'. Specifiek in een accountingcontext gaat het dus om pogingen door middel van manipulatie van tekstkenmerken oordelen en beslissingen van derden in voor het management van een onderneming gunstige zin te sturen. De manipulatie kan vele vormen aannemen, zoals we in paragraaf 3.2 zullen zien. Tegenover het impressiemanagement-paradigma staat wat Merkel-Davies 
en Brennan (2007, paragraaf 2) aanduiden als het incremental information'-paradigma: de informatieverstrekking dient de oordeels- en besluitvorming van belanghebbenden te verbeteren door het verminderen van de informatieasymmetrie tussen het ondernemingsmanagement en deze belanghebbenden. Daarbij wordt uitgegaan van de semi-sterke dan wel sterke vorm van efficiëntie van vermogensmarkten. Merkl-Davies en Brennan (2007) noemen veel studies waarin de externe validiteit van beide paradigmata is onderzocht en aangetoond.

In paragraaf 3.2 bespreken we enkele strategieën door middel waarvan impressiemanagement vorm wordt gegeven. In het bijzonder gaan we in op die strategieën waarin taalkundige manipulatie centraal staat. Wij sluiten deze paragraaf af met drie paradigmatische kanttekeningen, waarna in paragraaf 3.3 twee gangbare groepen manipulatiestrategieën binnen accounting worden besproken, die vervolgens worden geplaatst naast een methode van tekstanalyse uit de letteren.

In paragraaf 3.4 laten we zien hoe de sociale psychologie en letterkunde diverse suggesties voor toekomstig onderzoek kunnen leveren.

\subsection{Zeven strategieën}

Merkl-Davies en Brennan (2007, figuur 1, p. 128) onderscheiden de volgende zeven strategieën door middel waarvan impressiemanagement in narratieve teksten vorm kan worden gegeven:

1. Manipulatie van de leesbaarheid van gepresenteerde informatie met de focus op syntactische kenmerken ('reading ease manipulation'). Achterliggende veronderstelling is dat 'slecht nieuws' versluierd wordt ('obfuscation hypothesis').

2. Manipulatie van het taalgebruik: retorische manipulatie. Hier geldt dezelfde achterliggende veronderstelling als bij strategie 1 .

3. Manipulatie van de behandelde thema's: thematische manipulaties. Achterliggende veronderstelling is dat 'goed nieuws' benadrukt dient te worden.

4. Manipulatie door middel van keuzes betreffende de structuur waarin teksten worden aangeboden, annex foto's en/of grafieken. In tegenstelling tot de strategieën 1 tot en met 3 kan de informatie nu ook cijfermatige informatie betreffen.

5. Manipulatie van cijfermatige informatie in het kader van 'performance'-vergelijkingen.

6. Manipulatie van cijfermatige informatie in het kader van de methode van winstberekening ('earnings management').

7. Manipulatie van verbale informatie door middel van attributies van ondernemingsprestaties aan interne dan wel externe partijen. In tegenstelling tot de strategieën 1 tot en met 6 is hier geen sprake van het achterhouden ('concealment') van informatie.
Wij beperken ons in dit artikel tot de strategieën 1 tot en met 3 , die alle drie betrekking hebben op de manipulatie van verbale informatie. Strategie 1 is in de vorige paragraaf besproken. De strategieën 2 en 3 worden in paragraaf 3.3 besproken.

Wij spreken hier van modern leesbaarheidsonderzoek, en wel om de volgende redenen:

1. De aanvechtbare louter syntactische leesbaarheidsformules die centraal staan bij de traditionele studies, worden aangevuld met taalkundige inhoudsanalysetechnieken, waarbij bijvoorbeeld wordt ingegaan op stijlfiguren, toonzetting en diverse andere kenmerken van het taalgebruik. Naast de syntaxis van teksten vormt de context van informatieverstrekking expliciet onderdeel van de analyses.

2. De keuze van het paradigma impressiemanagement impliceert een oriëntatie op het benadrukken van 'goed nieuws' en/of het versluieren van 'slecht nieuws'. In elk geval is er sprake van onderzoek naar het achterhouden van informatie, dit in tegenstelling tot de analyses vallende onder de eerste (traditionele) strategie.

Met een drietal kanttekeningen van paradigmatische aard ronden wij deze paragraaf af. De eerste kanttekening betreft het partiële beeld dat uit impressiemanagementstudies volgt. In voetnoot 11 noemden wij eerder al enkele andere paradigmata die het inzicht kunnen verbreden. Davison (2008) noemt nog weer andere invalshoeken die hun ontstaan danken aan de sociale wetenschappen. Met name vanuit de linguïstiek en de sociale psychologie zijn voorstellen gedaan waardoor het moderne leesbaarheidsonderzoek nieuwe impulsen heeft gekregen.

De tweede kanttekening benadrukt het feit dat het merendeel van de impressiemanagement-studies uitgaat van het standpunt van de verstrekkers van informatie. Gebruikersstudies komen relatief weinig voor, zelfs niet in de beperkte betekenis van vooraf rekening houden met mogelijke reacties van de ontvangers van informatie. ${ }^{11} \mathrm{Op}-$ nieuw is er daarom sprake van een dreigende verschraling van het onderzoekveld, aangezien tal van voor het onderzoek vruchtbare concepten zoals beperkte rationaliteit en heuristische besluitvorming buiten beeld blijven. ${ }^{12}$

De derde en laatste kanttekening wijst op het verschijnsel dat vrijwel alle onderzoekingen zijn verricht in Angelsaksische landen. Ook hier zien wij een bepaalde eenzijdigheid dreigen, omdat wordt voorbijgegaan aan de implicaties van cultuurverschillen op het gebruik van taal in diverse in cultureel opzicht verschillende landen. ${ }^{13}$

Methodologische bezinning is tegen de achtergrond van de drie kanttekeningen geen luxe. Slechts weinig auteurs hebben evenwel oog voor methodologische problemen. Gunstige uitzonderingen vormen onder anderen Jones en 
Shoemaker (1994), Sydserff en Weetman $(1999,2002)$ en Merkl-Davies en Brennan (2007).

\subsection{Toepassingen binnen accounting}

\section{3 .1}

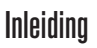

In deze paragraaf vatten wij diverse studies samen waarin wordt aangetoond dat narratieve teksten, zoals het directieverslag, bepaalde taalkenmerken bevatten waarmee getracht wordt de percepties van de lezers van deze teksten in voor de onderneming positieve zin te beïnvloeden. Aerts (1994, p. 337) sprak reeds van 'biased accounting language' en typeerde deze taal als 'not simply the outcome of a straight-forward data analysis process'. Alvorens nader in te gaan op de hiervoor genoemde strategieën 2 en 3 merken wij nog op dat Merkl-Davies en Brennan (2007) relatief veel aandacht besteden aan studies verricht in het kader van strategie 1 . De auteurs noemen in totaal 18 'reading ease manipulation'-studies; zeven daarvan werden reeds door Jones en Shoemaker besproken in hun overzicht van studies tot en met 1993. Twee relatief oude studies werden niet door Jones en Shoemaker (1994) genoemd (Adelberg, 1979; Smith en Taffler, 1992). De overige negen studies beslaan de periode 1995-2008 (Courtis, 1995, 1997, 2004; Sydserff en Weetman, 1999, 2002; Clatworthy en Jones, 2001; Rutherford, 2003; Li, 2008 en Merkl-Davies, 2007). In elk van deze negen studies wordt gezocht naar verklaringen van het (syntactisch) gemeten leesbaarheidsniveau. ${ }^{14}$ De 18 studies vormen als het ware mengvormen van traditioneel en modern leesbaarheidsonderzoek.

De strekking van de gevonden resultaten wijkt niet af van de conclusies die reeds in 1994 waren bereikt: onderzoekingen naar de samenhang tussen diverse ondernemingskenmerken en de leesbaarheid van narratieve teksten, zoals gemeten met diverse leesbaarheidsmaatstaven, leveren geen eenduidige uitkomsten op. Evenmin als dat voor 1994 het geval was kan op grond van de 'reading ease manipulation'-studies uit de periode 1995-2008 gesteld worden dat variabelen als winstgevendheid, ondernemingsgrootte, bedrijfstak en media-aandacht de leesbaarheid en variaties daarin afdoende verklaren.

\subsubsection{De retorische manipulatiestrategie}

Onderzoek in het kader van de retorische manipulatiestrategie wordt niet langer gedomineerd door de toepassing van leesbaarheidsformules, maar door zogenaamde 'content analysis' (inhoudsanalyse) (Sydserff en Weetman, 2002). Dat betekent dat onderzocht wordt in hoeverre er sprake is van gemanipuleerde informatieverstrekking door middel van toepassing van diverse taalkundige middelen, zoals suggestief taalgebruik, eufemismen en andere stijlfiguren, gebrek aan helder taalgebruik en door een dusdanige structurering van de tekstopbouw dat er twijfel ontstaat over oprechtheid en waarheidsgetrouwheid. Kortom, de vraag hoe iets wordt gezegd is belangrijker dan de vraag wat er wordt gezegd. Merkl-Davies en Brennan (2007, tabel 4, p. 140) hebben vier retorische manipulatiestudies getraceerd (Thomas, 1997; Jameson, 2000; Sydserff en Weetman, 2002; Yuthas et al., 2002).

De binnen accounting gevonden onderzoekresultaten zijn niet eenduidig. Thomas (1997, p. 63) concludeert bijvoorbeeld: 'management letters suggest and imply, but they do not lie'. In haar steekproef, die slechts één (!) onderneming omvat, constateert zij in aan aandeelhouders verstrekte informatie ('management letters') verschillen in taalgebruik tussen winstgevende en verlieslatende jaren met een relatief feitelijke en objectieve toonzetting van 'slecht nieuws'. Jameson (2000) vindt eveneens verschillen in narratieve teksten van 200 verschillende ondernemingen, i.c. goed en minder goed opererende beleggingsfondsen. $\mathrm{Zij}$ verklaart de gevonden verschillen vooral door te wijzen op verschillen in complexiteit van de onderzochte organisaties, en niet zo zeer door verschillen in de toepassing van impressiemanagement.

Sydserff en Weetman (2002) vinden evenmin overtuigend bewijs voor de bewering dat impressiemanagement als manipulatiestrategie wordt toegepast. De auteurs stellen zelfs dat de ondernemingsleiding 'even-handed in presenting narrative information' is. Ook Yuthas et al. (2002) hebben twijfels omtrent het toegepast worden van impressiemanagement. Volgens hen streven ondernemingen veeleer naar het verstrekken van geloofwaardige informatie.

\subsubsection{De thematische manipulatiestrategie}

De inhoudsanalyse in het kader van de thematische manipulatiestrategie wijkt gradueel af van die passend bij de retorische manipulatiestrategie. In beide gevallen wordt onder andere ingegaan op positieve en negatieve sleutelwoorden, toonzetting van teksten (optimistisch, neutraal, pessimistisch) en tekstuele complexiteit. Er zijn evenmin verschillen voor wat betreft de aard van de informatie (die is verbaal), de onderzochte tekstbestanden (veelal het directieverslag) en de verklarende variabelen (veelal diverse ondernemingsprestatiekenmerken). Merkl-Davies en Brennan (2007, figuur 1, p. 128) stellen dat het verschil tussen beide benaderingen drie aspecten betreft:

1. het gedrag van de ondernemingsleiding;

2. de aard van de manipulatie;

3. de focus van de manipulatie. Retorische manipulatie gaat uit van de veronderstelling dat het management 'slecht nieuws' wil versluieren door manipulatie bij de presentatie van informatie, in het bijzonder de leesbaarheid.

Thematische manipulatie gaat uit van de veronderstelling dat het management 'goed nieuws' wil benadrukken door manipulatie bij de openbaarmaking ervan, in het bijzonder de themakeuzes. 
Wij beperken ons tot vier accountingstudies die uitgaan van impressiemanagement; drie van de vier gaan uit van het perspectief van de verstrekkers van informatie (Abrahamson en Park, 1994; Smith en Taffler, 2000 en Clatworthy en Jones, 2003), terwijl Matsumoto et al. (2011) het gebruikersperspectief toepassen. De studies van Smith en Taffler (2003) betreffen Britse ondernemingen, de andere onderzoekingen zijn uitgevoerd op basis van Amerikaanse tekstbestanden. Kenmerkend voor alle studies is dat in de onderzochte tekstbestanden relatief veel aandacht is voor het minimaliseren van 'slecht nieuws' ten gunste van 'goed nieuws. ${ }^{15}$ Smith en Taffler (2000) constateren in hun onderzoek naar de toepassing van positieve/ negatieve sleutelwoorden in de directieverslagen van Britse ondernemingen dat er sprake is van vertekeningen ('biases') in de richting van 'goed nieuws' en dat de vertekeningen samenhangen met de financiële gang van zaken. Abrahamson en Park (1994) wijzen er op, na onderzoek van 1118 directieverslagen, dat het achterhouden van 'slecht nieuws' wordt beperkt door toezichthoudende commissarissen, door grote institutionele beleggers en door controlerende accountants. Clatworthy en Jones (2003) vonden na onderzoek van 100 directieverslagen geen bewijs voor de bewering dat vertekeningen in de behandelde thema's samenhangen met de financiële resultaten. De resultaten van de drie verstrekkersstudies zijn dus niet eenduidig. Matsumoto et al. (2011) concludeerden na een omvangrijk onderzoek van 'conference call transcripts' dat financieel-analisten enige scepsis hebben ten aanzien van positief getoonzette bewoordingen van managers, met name als het toekomstgerichte uitspraken betreft.

\subsubsection{Genreanalyse}

Binnen de letteren en de communicatiewetenschap zijn diverse methoden voor de analyse van teksten ontwikkeld. Schellens en Steehouder (2010) onderscheiden de volgende vijf methoden: ${ }^{16}$

1. functionele analyse;

2. coherentieanalyse;

3. retorische analyse;

4. argumentatieanalyse;

5. genreanalyse.

In het algemeen kan gesteld worden dat toepassing van deze methoden tijdrovend is vanwege de vereiste gedetailleerde aanpak. Dat blijkt bijvoorbeeld uit drie accountingstudies die wij hebben getraceerd waarin genreanalyse is toegepast (Rutherford, 2005; De Groot, 2008; Henry, 2008). Met betrekking tot de andere methoden zijn ons geen toepassingen op accountingteksten bekend. Genreanalyse omvat meer dan de hiervoor genoemde retorische en thematische analyses; er wordt tevens gezocht naar kenmerken van de communicatieve context ter verklaring van tekstthema's, tekststructuren en lexico-grammaticale elementen (Schuurs en De Groot, 2010, pp. 162-197). Tekstanalyses geschieden dus in termen van inhoud, structuur en stijl. Eigenlijk omvat genreanalyse alle door MerklDavies en Brennan (2007) genoemde strategieën.

De Groot (2008) onderzocht Engelstalige jaarverslagen van Nederlandse ondernemingen met een AEX-notering en Britse ondernemingen die op de London Stock Exchange zijn genoteerd. Vanuit een 'preparer's'-perspectief constateerde zij tal van (subtiele) verschillen in taalgebruik tussen beide groepen. Uit een door haar opgezet experiment vanuit een 'users'-perspectief bleek voorts dat de percepties van financieel-analisten over ondernemingen mede bepaald worden door kenmerken van het taalgebruik in directieverslagen. Zo bleek dat aan Britse ondernemingen een positiever imago werd toegekend dan aan Nederlandse ondernemingen en dat louter en alleen door diverse taalkundige verschillen in directieverslagen. De taalkundige verschillen leidden evenwel niet tot afwijkende beoordelingen van aantrekkelijkheid en geloofwaardigheid.

Rutherford (2005) heeft genreanalyse toegepast op de Operating and Financial Reviews uit 1998 van 44 Britse ondernemingen. Dit onderzoek richtte zich vooral op het meer of minder frequent voorkomen van 90 financieel-administratieve sleutelwoorden. Rutherford concludeerde dat het toegepaste taalgebruik een positieve 'bias' heeft en dat dit in sterkere mate het geval is naarmate de ondernemingsresultaten verslechteren.

Henry (2008) onderzocht door middel van genreanalyse 1366 persberichten van Amerikaanse ondernemingen op de gevolgen van variatie in toonzetting, tekstuele complexiteit en lengte. $\mathrm{Zij}$ concludeerde onder andere dat de toonzetting van persberichten van invloed is op de reacties van de aandeelhouders.

\subsection{Aanbevelingen voor toekomstig onderzoek vanuit lingüistisch perspectief}

Genreanalyse blijkt een zinvolle bijdrage te kunnen leveren aan het onderzoek naar narratieve accountingteksten (Rutherford, 2005; De Groot, 2008; Henry, 2008). Deze drie studies illustreren een ontwikkeling waarbij leesbaarheidsformules meer en meer buiten beeld raken ten koste van aandacht voor diverse taalkundige en contextkenmerken van accountingteksten, al dan niet aangevuld met aandacht voor intenties van de ondernemingsleiding. Het oudste voorbeeld van toepassing van begrippen uit de linguïstiek leveren Sydserff en Weetman (1999, 2002). Deze Britse onderzoekers hebben maatstaven ontwikkeld ter bepaling van bijv. het gebruik van de lijdende vorm in teksten (2002), de cohesie van teksten (in hoeverre wordt een tekst een geheel dankzij specifieke verbindingswoorden?) (1999) en de coherentie (in hoeverre hangen opeenvolgende subdelen van een tekst samen?) (1999). Voor wat betreft de toepassing van de lijdende vorm is de achterliggende gedachte dat dit getuigt van een relatief slechte gang van zaken (zie ook Thomas, 1997, pp. 52-53). Een hoge mate van cohesie en coherentie zal de leesbaarheid 
en begrijpelijkheid van teksten kunnen doen toenemen. Voor zover ons bekend zijn er geen empirische accountingstudies verschenen ter toetsing van de toepasbaarheid van de door Sydserff en Weetman voorgestelde maatstaven. De onderzoekers hebben wel vastgesteld dat de scores op hun maatstaven slecht correleren met de scores volgens de traditionele leesbaarheidsformules. Hier liggen mogelijkheden voor toekomstig onderzoek.

Uit recente studies blijkt dat linguïstische indicatoren in verband kunnen worden gebracht met achterliggende psychologische processen. Dit psycholinguïstische onderzoek steunt onder anderen op het werk van Newman et al. (2003) en Pennebaker et al. (2003). Voor het vakgebied accounting betekent deze benadering bijvoorbeeld dat (kenmerken van) taalgebruik in directieverslagen en het sociaalpsychologische concept impressiemanagement worden onderzocht op hun samenhang. Essentieel is het woordgebruik in de verstrekte informatie, niet de inhoud. Newman et al. (2003, p. 674) stellen in dit verband bijvoorbeeld '... liars can be reliably identified by their words not by what they say but how they say it'. De analyse van het woordgebruik is veelal gebaseerd op het gebruik van persoonlijke voornaamwoorden in teksten, naast het voorkomen van verbindingswoorden en woorden die emoties of doelstellingen tot uiting brengen. Zo concludeerden Pennebaker et al. (2003) na onderzoek van het taalgebruik van leugenaars dat dit taalgebruik wordt gekenmerkt door het vermijden van sommige persoonlijke voornaamwoorden; ook emotiewoorden en exclusieve woorden worden minder vaak gehanteerd dan door personen die waarheidsgetrouwe informatie verstrekken. Wij noemen twee accounting studies die in dit moderne psycholinguïstische kader passen: Cho et al. (2010) en Merkl-Davies et al. (2011). Beide studies kunnen ideeën leveren voor toekomstig onderzoek.

Cho et al. (2010) hebben de toonzetting ('tone') in de duurzaamheidsverslagen over het jaar 2002 van 190 Amerikaanse beursgenoteerde ondernemingen onderzocht. Het onderzoek richtte zich met name op de mate van optimisme en stelligheid die de teksten uitstraalden. Geconcludeerd werd dat (met betrekking tot duurzaamheid) relatief slecht presterende ondernemingen een significant positievere toonzetting hanteren dan relatief goed presterende ondernemingen, zij het dat de verstrekte informatie niet al te stellig is geformuleerd. In toekomstig onderzoek zou onderzocht kunnen worden in hoeverre deze conclusie standhoudt met betrekking tot andere dan duurzaamheidsverslagen, in hoeverre de conclusie ook geldt voor in Europa genoteerde ondernemingen en in hoeverre de aard van de onderzochte ondernemingen en de specifieke tijdsperiode van invloed zijn.

Merkl-Davies et al. (2011) hebben getracht in het taalgebruik zoals toegepast in de directieverslagen over 2002 van 93 beursgenoteerde Britse ondernemingen, aanwijzingen te vinden voor impressiemanagement met toepassing van bevindingen uit het psychologisch onderzoek van Newman et al. (2003). Misleidende informatie heeft volgens Newman et al. (2003) de volgende kenmerken: ze is relatief kort, bevat relatief weinig verwijzingen naar derden, bevat zowel meer positieve als negatieve emotiewoorden en is relatief niet al te complex. Geconcludeerd werd dat de extern verstrekte informatie relatief gunstig is, maar dat niet gesproken kan worden van inconsistenties ten opzichte van intern beschikbare informatie. In het geval van relatief slechte prestaties bleek de ondernemingsleiding vaak de neiging te hebben grammaticaal complexe constructies te gebruiken. Mutatis mutandis gelden hier dezelfde onderzoeksuggesties als zojuist geformuleerd naar aanleiding van Cho et al. (2010).

Wij sluiten deze paragraaf af met een opmerking van onderzoekstechnische aard. Modern onderzoek, zoals dat van Cho et al. (2010) en Merkl-Davies et al. (2011), steunt in belangrijke mate op taalsoftware die het mogelijk maakt op automatische wijze intelligente uitspraken te doen over teksteigenschappen van omvangrijke databestanden. De twee bekendste tekstanalyseprogramma's zijn DICTION (onder anderen toegepast door Cho et al., 2010) en LIWC (onder anderen toegepast door Merkl-Davies et al., 2011). ${ }^{17}$ Met DICTION kan bijvoorbeeld onderzocht worden in hoeverre de toonzetting van accountingteksten als positief kan worden gekarakteriseerd en wat dat dan betekent. Hier kan nog veel onderzoek worden verricht. LIWC kan gebruikt worden bij de bepaling en analyse van afwijkend taalgebruik. Opvallend is hier de opkomst van door onderzoekers zelfontwikkelde financieel-administratieve woordenlijsten (bijv. Loughran en McDonald, 2011). Er moet nog veel onderzoek gedaan worden naar de sterke en zwakke punten van de vele tekstanalyseprogramma's. Wel is reeds duidelijk hoe simplistisch de traditionele leesbaarheidsformules zijn; volgens hedendaagse taalonderzoekers, die hun werk op tal van letterkundige en sociaalpsychologische concepten baseren, meten deze formules noch de leesbaarheid, noch de begrijpelijkheid.

\section{Conclusies}

Dit artikel maakt duidelijk waarom het traditionele leesbaarheidsonderzoek aan het eind van de twintigste eeuw enigszins in de versukkeling is geraakt. Niet alleen is er veel kritiek geweest op de eenvoudige en louter syntactische leesbaarheidsformules (zie de kritiekpunten in paragraaf 2.2), maar ook de Cloze-testen kunnen fundamenteel bekritiseerd worden (zie de kritiekpunten in paragraaf 2.4). Staan we nu met lege handen? De meeste accountingonderzoekers lijken zich slechts ten dele bewust te zijn van de bedoelde kritiekpunten en blijven leesbaarheidsformules toepassen (bijv. Li, 2008). Het moderne leesbaarheidsonderzoek is nog onvoldoende uitgekristalliseerd met betrekking tot het concept leesbaarheid. Welk paradigma zal gaan domineren is vooralsnog onduidelijk. 
De retorische en thematische manipulatiestudies leveren geen eenduidige resultaten op. In het algemeen kan niet gesteld worden dat taalmanipulaties vooral bij slecht presterende ondernemingen voorkomen. De retorische manipulatiestudies leveren geen overtuigend bewijs voor de bewering dat ondernemingen narratieve teksten gebruiken om negatieve resultaten te versluieren. De thematische manipulatiestudies evenwel leiden tot de conclusie dat enige vertekening in de themakeuze niet valt te ontkennen, met name in het geval van een relatief slechte gang van zaken. Deze conclusie geldt des te sterker naarmate naast het directieverslag ook wordt gekeken naar persberichten en 'conference calls'. Genreanalyses versterken de opvatting dat taal wordt gebruikt om de percepties van buitenstaanders in voor de onderneming gunstige zin te beïnvloeden.

In het algemeen gesproken menen wij toch te kunnen stellen dat de onderzoeksresultaten in de richting wijzen van de toepassing van impressiemanagement, vooral in de vorm van het benadrukken van 'goed nieuws'. Hiermee hebben we geen uitspraken gedaan over het fenomeen impressiemanagement in relatie tot andere strategieën, bijvoorbeeld 'earnings management' en de wijze waarop attributies van resultaten plaatsvinden. De aanwijzingen vanuit deze strategieën voor het bestaan van impressiemanagement zijn sterker dan die vanuit de in deze paragraaf door ons besproken manipulatiestrategieën (MerklDavies en Brennan, 2007, p. 181: 'Evidence suggests that firms engage in impression management by using performance attributions'). De bespreking van andere strategieën dan de retorische en thematische manipulatie gaat het bestek van dit artikel te boven (zie Merkl-Davies en Brennan, 2007).

Een ons inziens belangrijke vraag die in het voorgaande niet aan bod kwam luidt: kunnen de door ons besproken taalkundige manipulatiestrategieën vanuit een ruimer sociaalpsychologisch onderzoekparadigma worden bestudeerd, zoals overwegingen betreffende begrippen als imagoschade en reputatierisico, en zo ja, wat betekent dat dan voor de te onderzoeken kwesties? Immers in het gedragsmatige onderzoek in het algemeen vraagt men zich af in hoeverre gebruikers van informatie gevoelig zijn voor de manipulatie van gepresenteerde discretionaire informatie; tevens zoekt men naar factoren die deze gevoeligheid bepalen (zoals expertise en diverse persoonlijkheidskenmerken). Deze zeer ruime vraagstelling gaat het bestek van dit artikel ver te boven (zie: Merkl-Davies en Brennan, 2007; Knoops, 2010, hoofdstuk 7). Dat geldt evenzeer met betrekking tot interessante (politieke) vraagstellingen zoals: dient narratieve informatieverstrekking niet strakker te worden gereguleerd?; zou de controlerende accountant geen meeromvattende controle op narratieve teksten dienen te verrichten dan de huidige controle die gericht is op consistentie ten opzichte van de jaarrekening?

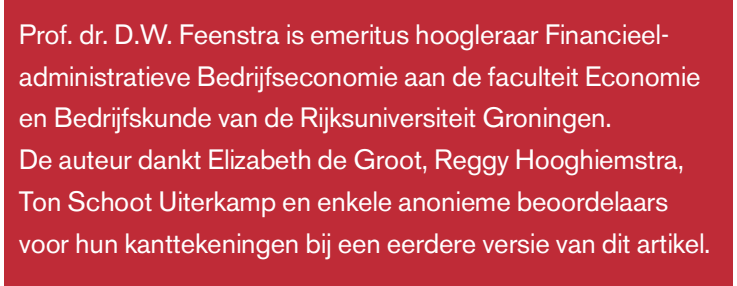

\section{Noten}

In het Plain English Handbook staan richtlijnen voor de openbaarmaking van narratieve informatie annex enkele schrijftips ter bevordering van de leesbaarheid (zoals: maak korte zinnen, wees concreet en duidelijk, hanteer de bedrijvende in plaats van de lijdende vorm, vermijd jargon, geef puntsgewijze opsommingen en gebruik geen dubbele ontkenningen). De door de regelgevende organen genoemde kwalitatieve kenmerken verschillen onderling gering en zijn bovendien in de tijd gezien niet onveranderlijk. Zie Knoops (2010) en Feenstra (2011).

2. Staphorsius (1994) geeft een uitgebreide samenvatting, ook voor wat betreft ontwikkelingen in Nederland. Internationaal gezien is de studie van Klare (1963) opvallend: van bijna 500 studies wordt een geannoteerde samenvatting gegeven.

Wij gaan niet in op de verschillen in benaming die er bestaan tussen Nederlandse en An- gelsaksische directieverslagen. Verschillen in corporate governance structuren en de daaruit voortvloeiende verschillen in benaming zijn in het kader van dit artikel niet relevant. Zie voor gedetailleerde beschrijvingen De Groot (2008) en Hooghiemstra en Van Manen (2004).

4_ Zie Courtis (1986), p. 287, tabel 2.

5 In Nederland bestaan naast de CLIB minstens drie commerciële programma's waarvan door de makers beweerd wordt dat het taalniveau van een tekst ermee kan worden vastgesteld. Het betreft Texamen van Bureau Taal, Klinkende Taal van het taaltechnologiebedrijf Gridline en Accessibility Leesniveau Tool van de Stichting Accessibility. De programma's omvatten meer tekstkenmerken dan in de zojuist genoemde formules voorkomen (o.a. lengte van de tekst, aantal formele woorden, aantal laagfrequente woorden, aantal passief- en tangconstructies, vaktermen, dubbele ontkenningen). Met betrekking tot geen van de drie programma's is wetenschappelijk onderzoek gepubliceerd waaruit blijkt dat ze betrouwbaar en valide zijn. Wij besteden er verder geen aandacht aan, ook omdat er geen toepassingen binnen accounting bekend zijn.

6 Continentaal-Europese accounting-leesbaarheidsonderzoekingen zijn ons niet bekend. Voor de vakgebieden communicatiewetenschap, letteren en sociale psychologie ligt dat anders (Staphorsius, 1994; Merkl-Davies en Brennan, 2007).

z. In 15 van de 32 publicaties wordt meer dan één probleemveld onderzocht.

8 Niet iedereen deelt deze opvatting. Adelberg en Razek (1984, p. 109) bijvoorbeeld beschouwen beide begrippen als synoniemen ('for the sake of clarity', noot 1).

9 De procedure ontleent haar benaming aan het begrip 'closure' uit de Gestaltpsychologie (Taylor, 1957). 
10. Merkl-Davies en Brennan onderkennen uiteraard dat vrijwillige openbaarmaking vanuit diverse andere paradigmata kan worden bestudeerd. Te denken valt onder andere aan: 'agencytheorie', signaleringstheorie, legitimiteitstheorie, 'stakeholder'-theorie, politieke economie en institutionele theorie (2007, par. 3.1, pp. 123-125). Wij bespreken de overeenkomsten en verschillen tussen al deze theorieën hier niet (zie Knoops, 2010; Merkl-Davies en Brennan, 2011). We stellen slechts dat impressiemanagement uitgaat van zwak efficiënte vermogensmarkten, een uitgangspunt dat door veel onderzoekers evenwel niet wordt gedeeld (zie tabel 1 in Merkl-Davies en Brennan, 2007).

11. Prakash en Rappaport (1977) spreken in dit laatste geval van 'information inductance'.

1.2. Merkl-Davies en Brennan (2007); zie de paragrafen 4.0 en 5.3. Henry (2008) vormt één van de weinige uitzonderingen; evenzo Abrahamson en Park (1994).

12. Hooghiemstra (2003) stipt dit probleem aan in het kader van zijn dissertatie waarin de attributietheorie centraal staat (strategie nummer
7 van Merkl-Davies en Brennan, 2007). Omdat een taalkundige invalshoek niet centraal staat in de attributietheorie gaan wij er niet nader op in. Die theorie kent andere belangrijke invalshoeken, zoals die van de sociale psychologie, de communicatiewetenschap en de economische agencytheorie. Zie Hooghiemstra, 2003, pp. 11-42.

14 In paragraaf 2.3 noemden wij dit probleemveld nummer 3 .

15. In de communicatiewetenschap spreekt men in dit verband van het Pollyanna-principe (Hildebrandt en Snyder, 1981). Pollyanna staat voor de eeuwige optimist. De term is ontleend aan een kinderboek van Eleanor Porter uit 1913. 16. Uit de opsomming van vijf methoden blijkt dat er geen min of meer vaststaande methode van tekstanalyse bestaat. De analyses omvatten een veelheid aan aspecten van de tekst: opbouw, stijl, de mate waarin een beroep gedaan wordt op ethos/logos/pathos en de overtuigingsmiddelen die worden ingezet (zie Schuurs en Breij, 2010, pp. 106-117). Laatstgenoemde auteurs bepleiten het volgende sjabloon voor tekstanalyse:
- identificatie van het ingenomen standpunt in de tekst;

- analyse van de opbouw van de tekst;

- identificeren van de aspecten ethos, logos en pathos;

- toetsing aan de vier stijldeugden correctheid, helderheid, gepastheid en fraaiheid;

- analyse van vier toegepaste stijlsoorten soberheid, elegantie, verhevenheid en overtuigingskracht;

- analyse van retorische figuren (onder andere stijfliguren zoals de hyperbool en het eufemisme).

17 DICTION en LIWC zijn ontwikkeld door resp. Hart (2000) en Pennebaker et al. (2003). Lowe (2011) noemt daarnaast nog 19 andere programma's voor tekstanalyse. In Li (2010) worden veel accountingtoepassingen genoemd. In Nederland heeft het T-scan-programma van Kraf en Pander Maat (2009) enige bekendheid verworven; accountingtoepassingen zijn ons niet bekend.

\section{Literatuur}

- Abrahamson, E. en C. Park (1994), Concealment of negative organizational outcomes: An agency theory perspective, Academy of Management Journal, vol. 37, no. 5, pp. 1302-1334.

- Adelberg, A.H. (1979), Narrative disclosures contained in financial reports: Means of communication or manipulation, Accounting and Business Research, vol. 10, pp. 179-189.

- Adelberg, A.H. en J.R. Razek (1984), The cloze procedure: A methodology for determining the understandability of accounting textbooks, The Accounting Review, vol. 59, no. 1, pp. 109-122.

- Aerts, W. (1994), On the use of accounting logic as an explanatory category in narrative accounting disclosures, Accounting, Organizations and Society, vol. 19, no. 4/5, pp. 337-353.

- Anderson, R.C. en A. Davison (1988), Conceptual and empirical bases of readibility formulas, in: A. Davison en G.M. Green, Linguistic complexity and text comprehension: Readability issues reconsidered (pp. 23-53), Hillsdale, N.J.: Lawrence Erlbaum.

- Baker, H.E. en D.D. Kare (1992), Relationship between annual report readability and corporate financial performance, Management Research News, vol. 15, no. 1, pp. 1-4.

- Barnett, A. en K. Leoffler (1979), Readability of accounting and auditing messages, Journal of Business Communication, vol. 16, no. 1, pp. 49-59.

- Bormuth, J.R. (1966), Readability: A new approach, Reading Research Quarterly, vol. 1 , pp. 79-132.

- Cho, C.K., R.W. Roberts en D.M. Patten (2010), The language of U.S. corporate environmental disclosure, Accounting, Organizations and Society, vol. 35, no. 4, pp. 431-443.

- Clatworthy, M. en M.J. Jones (2001), The effect of thematic structure on the variability of annual report readability, Accounting, Auditing and Accountability Journal, vol. 14 , no. 3, pp. 311-326.

- Clatworthy, M. en M.J. Jones (2003), Financial reporting of good news and bad news: Evidence from accounting narratives, Accounting and Business Research, vol. 33, no. 3, pp. 171-185.

- Courtis, J.K. (1986), An investigation into annual report readability and corporate riskreturn relationships, Accounting and Business Research, vol. 16, pp. 285-294.
- Courtis, J.K. (1995), Readability of annual reports: Western versus Asian evidence, Accounting, Auditing and Accountability Journal, vol. 8, no. 2, pp. 4-17.

- Courtis, J.K. (1997), Annual report readability variability: Tests of the obfuscation hypothesis, Accounting, Auditing and Accountability Journal, vol. 11, no. 4, pp. 459-471.

- Courtis, J.K. (2004), Corporate report obfuscation: Artefact or phenomenon? British Accounting Review, vol. 36, no. 3, pp. 291312.

- Davison, J. (2008), Repetition, rhetoric, reporting and the 'dotcom' era: Words, pictures, intangibles, Accounting, Auditing and Accountability Journal, vol. 21, no. 6, pp. 791826.

- Feenstra, D.W. (2011), Reflecties op de kwaliteit van de jaarverslaggeving, Maandblad voor Accountancy en Bedrijfseconomie, vol. 85, no. 5, pp. 239-247.

- Flesch, R. (1948), A new readability yardstick, Journal of Applied Psychology, vol. 32, juni, pp. 221-233.

- Groot, E.B. de (2008), English annual reports in Europe, Dissertatie Radboud Universiteit Nijmegen. 
- Gunning, R. (1952), The technique of clear writing, New York: McGraw- Hill International Book Co.

- Hart, R.P. (2000), DICTION 5.0: The text analysis program, Thousand Oaks CA: Scolari/ Sage.

- Henry, E. (2008), Are investors influenced by how earnings press releases are written? Journal of Business Communications, vol. 45 , no. 4, pp. 363-407.

- Hildebrandt, H.W. en R.D. Snyder (1981), The Pollyanna hypothesis in business writing, Journal of Business Communications, vol. 18, no. 1, pp. 5-15.

- Hooghiemstra, R. (2000), Corporate communication and impression managementnew perspectives why companies engage in social reporting, Journal of Business Ethics, vol. 27, pp. 55-68.

- Hooghiemstra, R. (2003), The construction of reality: Cultural differences in self-serving behavior in accounting narratives, Dissertatie Erasmus Universiteit Rotterdam.

- Hooghiemstra, R. en J. van Manen (2004), The independence paradox: (im)possibilities facing non-executive directors in The Netherlands, Corporate Governance, vol. 12, no. 3, pp. 314-324.

- Jameson, D. (2000), Telling the investment story: A narrative analysis of shareholder reports, Journal of Business Communications, vol. 37, no. 1, pp. 7-38.

- Jansen, C. en L. Lentz (2008), Hoe begrijpelijk is mijn tekst? De opkomst, neergang en terugkeer van de leesbaarheidsformules, Onze Taal, vol. 77, no. 1. pp. 4-7.

- Jones, M.J. (1988), A longitudinal study of the readability of the chairman's narratives in the corporate reports of a U.K. company, Accounting and Business Research, vol. 18 no. 72, pp. 297-306.

- Jones, M.J. (1997), Critical appraisal of the cloze procedure's use in the accounting domain, Accounting, Auditing and Accountability Journal, vol. 10, no. 1, pp. 105 128.

- Jones, M.J. en P.A. Shoemaker (1994), Accounting narratives: A review of empirical studies of content and readability, Journal of Accounting Literature, vol. 13, pp. 142-184.

- Klare, G.R. (1963), The measurement of readability, Ames: lowa State University.

- Knoops, C.D. (2010), Verslaggevingstheorieën: Een wetenschapsfilosofische analyse, Dissertatie Erasmus Universiteit Rotterdam.
- Kothari, S.P., X. Li en J.E. Short (2009), The effect of disclosures by management, analysts, and financial press on the equity cost of capital: A study using content analysis, The Accounting Review, vol. 84, no.5, pp. $1639-1670$

- Kraf, R. en H. Pander Maat (2009), Leesbaarheidsonderzoek: oude problemen, nieuwe kansen, Tijdschrift voor Taalbeheersing, vol. 31, pp. 97-123.

- Lehavy, R., F. Li en K. Merkley (2011), The effect of annual report readability on analyst following and the properties of their earnings forecasts, The Accounting Review, vol. 86, no. 3, pp. 1087-1115.

- Li, F. (2008), Annual report readability, current earnings, and earnings persistence, Journal of Accounting and Economics, vol. 45, no. 2/3, pp. 221-247.

- Li, F. (2010), Textual analysis of corporate disclosures: A survey of the literature, Journal of Accounting Literature, vol. 29, pp. 143-165.

- Loughran, T. en B. McDonald (2011), When is a liability not a liability? Textual analysis, dictionaries, and 10-Ks, The Journal of Finance, vol. 86, no. 1, pp. 35-65.

- Lowe, W. (2011), Software for content analysis - A review; zie: www.ou.edu/cls/ online/lstd5913/pdf/rev.pdf.

- Matsumoto, D., M. Pronk en E. Roelofsen (2011), Do analysts mitigate optimism by management? The Accounting Review, vol. 86, no. 6, pp. 1383-1414.

- Means, T.L. (1981), Readability: An evaluative criterion of stockholder reaction to annual reports, Journal of Business Communication, vol. 24, no. 1, pp. 19-27.

- Merkl-Davies, D.M. (2007), The obfuscation hypothesis re-examined: Analysing impression management in narrative annual report documents, Dissertatie Bangor University.

- Merkl-Davies, D.M. en N.M. Brennan (2007), Discretionary disclosure strategies in corporate narratives: Incremental information or impression management? Journal of Accounting Literature, vol. 26, pp. 116-196.

- Merkl-Davies, D.M. en N.M. Brennan (2011), A conceptual framework of impression management: new insights from psychology, sociology and critical perspectives, Accounting and Business Research, vol. 41, no. 5, pp. 415-437.

- Merkl-Davies, D.M., N.M. Brennan en S.J. McLeay (2011), Impression management and retrospective sense-making in corporate narratives: A social psychology perspective,
Accounting, Auditing and Accountability Journal, vol. 24, no. 3, pp. 315-344.

- Miller, B.P. (2010), The effects of reporting complexity on small and large investor trading, The Accounting Review, vol. 85, no. 6 , pp. 2107-2143.

- Nederlandse Organisatie voor Wetenschappelijk Onderzoek (NWO) (2011) Begrijpelijke Taal: Fundamenten en toepassingen van effectieve communicatie, Onderzoeksprogramma.

- Nestvold, K.J. (1972), Cloze procedure correlation with perceived readability, Journalism Quarterly, vol. 49, pp. 592-594.

- Newman, M.L., J.W. Pennebaker, D.S. Berry en J.M. Richards (2003), Lying words, predicting deception from linguistic styles, Personality and Social Psychology Bulletin. vol. 29, no. 5, pp. 665-675.

- Pennebaker, J.W., M.R. Mehl en K. Niederhoffer (2003), Psychological aspects of natural language use: Our words, our selves, Annual Review of Psychology, vol. 54, pp. 547-577.

- Porter, E. (1913), Pollyanna, Boston: Colonial Press.

- Prakash, P. en A. Rappaport (1977) Information inductance and its significance for accounting, Accounting, Organizations and Society, vol. 2, no. 1, pp. 29-38.

- Rutherford, B.A. (2003), Obfuscation, textual complexity and the role of regulated narrative accounting disclosure in corporate governance, Journal of Management and Governance, vol. 7, pp. 187-210.

- Rutherford, B.A. (2005), Genre analysis of corporate annual report narratives: A corpus linguistics based approach, Journal of Business Communication, vol. 42, no. 4, pp. 324-348.

- Schellens, P.J. en M. Steehouder (red.) (2010), Tekstanalyse, Methoden en toepassingen (tweede druk), Assen: Van Gorcum.

- Schuurs, U. en B. Breij (2010), Retorische analyse, in: Schellens, P.J. en M. Steehouder (red.), Tekstanalyse (pp. 81-118), Assen: Van Gorcum.

- Schuurs, U. en E.B. de Groot (2010), Genreanalyse, in: Schellens, P.J. en M. Steehouder (red.), Tekstanalyse (pp. 162-197), Assen, van Gorcum.

- Securities and Exchange Commission (SEC) (1998), A Plain English Handbook: How to create clear SEC disclosure documents, SEC, Washington, DC. 
- Smith, J.E. en N.P. Smith (1971), Readability: A measure of performance of the communication function of financial reporting, The Accounting Review, vol. 46, juli, pp. 552561.

- Smith, M. en R. Taffler (1992), Readability and understandability: Different measures of the textual complexity of accounting narrative, Accounting, Auditing and Accountability Journal, vol. 5, no. 4, pp. 84-98.

- Smith, M. en R. Taffler (2000), The chairman's statement: A content analysis of discretionary narrative disclosures, Accounting, Auditing and Accountability Journal, vol. 13, no. 5, pp. 624646 .

- Staphorsius, G. (1994), Leesbaarheid en leesvaardigheid. De ontwikkeling van een domeingericht meetinstrument, Dissertatie Universiteit Twente.
- Stevens, K., K.C. Stevens en W.P. Stevens (1992), Measuring the readability of business writing: The Cloze procedure versus readability formulae, Journal of Business Communication, vol. 29, no. 4, pp. 367-382.

- Subramanian, R., R. Insley en R.D. Blackwell (1993), Performance and readability: A comparison of annual reports of profitable and unprofitable corporations, Journal of Business Communication, vol. 30, no. 1, pp. 49-60.

- Sydserff, R. en P. Weetman (1999), A texture index for evaluating accounting narratives: An alternative to readability formulae, Accounting, Auditing and Accountability Journal, vol. 12 , no. 4, pp. 459-480.

- Sydserff, R. en P. Weetman (2002), Developments in content analysis: A transitivity index and DICTION scores, Accounting, Auditing and Accountability Journal, vol. 15, no. 4, pp. 523-545.
- Taylor, L. (1953), 'Cloze procedure': A new tool for measuring readability, Journalism Quarterly, vol. 30, pp. 415-433.

- Taylor, L. (1957), 'Cloze' readability scores as indices of individual differences in comprehension and aptitudes, Journal of Applied Psychology, vol. 41, pp. 19-26.

- Thomas, J. (1997), Discourse in the marketplace: The making of meaning in annual reports, Journal of Business Communication, vol. 34, no. 1, pp. 47-66.

- Vogel, M. en C.W. Washburne (1928), An objective method of determining grade placement of children's reading material, Elementary School Journal, vol. 28, pp. 373381.

- Yuthas, K., R. Rogers en J.F. Dillard (2002), Communicative action and corporate annual reports, Journal of Business Ethics, vol. 41, no. 1/2, pp. 141-157. 